Tourism (1976) Number of visitors 117246 , gross receipts $\$ 49 \mathrm{mn}$ Consumer price index (Papeete only, $1970=100) 1976$ 171.5; growth $1970-769.4 \%$ pa

Budget (1976) Balanced at CFP Fr $14000 \mathrm{mn}=\$ 161 \mathrm{mn}=£ 89 \mathrm{mn}$ External trade (1976)

Imports: CFP Fr $25700 \mathrm{mn}=\$ 296 \mathrm{mn}=£ 164 \mathrm{mn}$

Exports: CFP Fr $1911 \mathrm{mn}=\$ 22 \mathrm{mn}=£ 12 \mathrm{mn}$

Main imports (1974) Food $20 \%$, petroleum products $7 \%$,

machinery, motor vehicles, cement, textiles

Main exports (1974) Re-exports (mainly nuclear material) $81 \%$, cocnut oil $15 \%$, vanilla $1 \%$

Main sources France $53 \%$, United States $19 \%$

Main destination France $82 \%$

\section{Gilbert Islands}

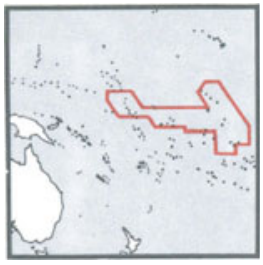

Location South-west Pacific Ocean

Comprises 28 main islands in 4 sections: the main Gilbert Island group of 16 main islands, Phoenix Islands of 8 main islands, Line Islands of 3 main islands, and Ocean Island (Banaba). The international date line divides the Gilbert and Ocean islands to the west from the Phoenix and Line Islands to the east

Land Area $860 \mathrm{~km}^{2}=330 \mathrm{mi}^{2}$, of which, Ocean Island $6 \mathrm{~km}^{2}$

Climate Tropical

Weather at Tarawa, 3 maltitude

Temperature : hottest month Oct $26-32{ }^{\circ} \mathrm{C}$, coldest July $25-31^{\circ} \mathrm{C}$

Rainfall (av monthly): driest month Nov $58 \mathrm{~mm}$, wettest Dec $317 \mathrm{~mm}$

Time Hours ahead of Hours behind

GMT (+) GMT (-)

Ocean Island $11 \frac{1}{2} \quad$ Phoenix Islands 11

Gilbert Islands $12 \quad$ Line Islands 10

Measures UK (imperial) system, converting to the metric system

Monetary unit Australian dollar $(\mathrm{A} \$)=100$ cents

Rate of exchange (1976 av): free $\$ 1.225=\mathrm{A} \$ 1, \mathrm{~A} \$ 1.474=£ 1$

\section{Summary}

Political UK colony, formerly the Gilbert and Ellice Islands (the Ellice Islands became a separate colony from October 1, 1975 as Tuvalu); internal self-government was obtained January 1, 1977 and full independence is planned. The Banabans, people of Ocean Island, wish to form an independent country associated with Fiji; they have been living on Rambi (Rabi) in the Fiji group since the end of the second world war. The Gilbert Islands are also known as Kingsmill Islands. Territorial member of the South Pacific Commission

Economic The main product has been phosphates obtained by the British Phosphate Commission from Ocean Island; the Gilbert Islands receive a royalty from these, as do the original inhabitants of Ocean Island (Banabans). Revenue from the phosphates is expected to end in 1979; the Banabans wish to restore some form of agriculture and a fishing industry to Ocean Island. Other main products in the Gilbert groups are coconuts, copra, bananas and fish

\section{People, resources and equipment}

Population 196041 000**, 197049 300*, $197659000^{*}$

Growth: 1960-70 1.9*\%pa, 1970-76 3.0*\%pa

Density (1976): $69 *$ people per $\mathrm{km}^{2}$

Vital statistics (including Tuvalu, rate per 1000 people, 1971):

births 22.3, deaths 6.5

Regions (population in 000,1968 ; total of 47578 )

Gilbert Islands (includes Tarawa) 44.2, Phoenix Islands nil,

Line Islands (includes Christmas Island) 1.2, Ocean Island 2.2

Town (population in 000, 1973) Tarawa (capital) 17

Race (1968) Micronesian 94**\%, Polynesian 3**\%, European 1**\%,

Mixed 1**\%

Language Gilbertese and English

Religion (1976) Roman Catholic 50**\%, Protestant 50**\%

Education (1973) Pupils 18 500**, teachers 420**

Labour force (including Tuvalu, 1968) 13279 ; seamen (1975) $1000 *$,

phosphate workers (1975) 1 150*
Personnel Scientists and engineers (including Tuvalu, 1971): 112

Physicians (1975): 26, 1 per 2270 people

Standard of living

National income per person (1976): $A \$ 800 * *=\$ 1000 * *=£ 500 * *$

Consumption per person (1975): energy $346 \mathrm{~kg}$ coal equivalent,

electricity (production) $85 * \mathrm{~kW} \mathrm{~h}$

Telephones (incl Tuvalu, Dec 1974): number 485,8 per 1000 people

Livestock $(000,1976)$ Pigs $10^{*}$, chickens $154^{*}$

Electrical capacity (1975) 2* megawatts

Hospital beds (including Tuvalu, 1974) 634, 1 per 99 people

Roads (1976) $640 * \mathrm{~km}=400 * \mathrm{mi}$, density $0.74 * \mathrm{~km}$ per $\mathrm{km}^{2}$

Ships (registered, 1977) 2, total of 1333 gross tons

Ports Betio Harbour (Tarawa), Ocean Island (moorings)

Airports Bonriki (Tarawa), Abemama, Tabiteuea, Butaritari, Marakei,

Nonouti, Beru

Radio sets (Dec 1975) 8200,140 per 1000 people

\section{Production, finance and trade}

\section{Gross domestic product}

1976 est: A $\$ 50^{* *} \mathrm{mn}=\$ 60 * * \mathrm{mn}=£ 34 * * \mathrm{mn}$

Main products (000 t) Agriculture (1976) Coconuts 74*, copra 11*,

bananas $3^{*}$, fish catch $0.7 *$ Other $(1975)$ Electricity $\left(\mathrm{mn} \mathrm{kW} \mathrm{h)} 5^{*}\right.$

phosphate rock 529

Transport traffic (including Tuvalu, 1975) Sea Goods loaded 535000 t, unloaded $20000 \mathrm{t}$

Budget (1977) Revenue: $\mathrm{A} \$ 11.77 \mathrm{mn}=\$ 13.1 \mathrm{mn}=£ 7.5 \mathrm{mn}$

Expenditure: $\mathrm{A} \$ 9.72 \mathrm{mn}=\$ 10.8 \mathrm{mn}=£ 6.2 \mathrm{mn}$

External trade (1976)

Imports: $\mathrm{A} \$ 10.1 \mathrm{mn}=\$ 12.3 \mathrm{mn}=£ 6.8 \mathrm{mn}$

Exports: A $\$ 18.1 \mathrm{mn}=\$ 22.2 \mathrm{mn}=£ 12.3 \mathrm{mn}$

Main imports Food $29 \%$, petroleum products, textiles, metal manufactures

Main exports Phosphates $95 \%$, copra 5\%

Main sources $^{\mathrm{a}}(1974) \quad \%$ of total Main destinations (1974) $\%$ of total

Australia

United Kingdom

New Zealand

Australia

ancluding trade of Tuvalu
New Zealand
United Kingdom 14

44

42

3

\title{
Guam
}

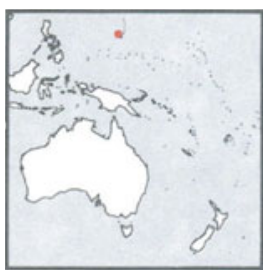

Location West Pacific Ocean

Southernmost of the Mariana Islands; Hawail

(United States) is about $6000 \mathrm{~km}$ to the east

Land Area $549 \mathrm{~km}^{2}=212 \mathrm{mi}^{2}$

Climate Tropical

Weather at Sumay, 20 maltitude

Temperature: hottest months May, June

$25-31{ }^{\circ} \mathrm{C}$, coldest Feb $23-29^{\circ} \mathrm{C}$

Rainfall (av monthly): driest month Apr $51 \mathrm{~mm}$, wettest Aug $376 \mathrm{~mm}$

Time 10 hours ahead of GMT (summer time, 11 hours ahead)

Measures US system

Monetary unit US dollar $(\$)=100$ cents

Rate of exchange (1976 av): $\$ 1.806=£ 1$

Summary

Political US territory, self-governing; the territory includes a major US naval and air base. Territorial member of South Pacific Commission Economic Tourism is important, and reduces dependence on military expenditure. Operation as a free port has encouraged some light industry, including watch assembly; crude oil refining began in 1970. The main agricultural export product is copra

\section{People, resources and equipment}

Population 196067 004, 197084 996, 1976102 000*

Growth: 1960-70 2.4\% pa, 1970-763.1*\% pa

Density (1976): $186 *$ people per $\mathrm{km}^{2}$

Vital statistics (rate per 1000 people, 1975): births 30.4 , deaths 4.2

Town (population in 000, 1970) Agana (capital) 5 (excluding armed forces)

Race (excluding armed forces) Chamorros (Indonesian/Filipino/Spanish)

and Micronesian 